American Medical Journal 1 (1): 59-70, 2010

ISSN 1949-0070

(C) 2010 Science Publications

\title{
Immunodeficiency Provides Partial Protection from Bone Loss Induced by Castration and Ovariectomy
}

\author{
Cedo M. Bagi, Edwin Berryman, Nels Hanson, Maria R. Moalli \\ and Catharine J. Andresen \\ Global Science and Technology, Worldwide Comparative Medicine, \\ Pfizer Inc, Groton, CT 06340, USA
}

\begin{abstract}
Problem Statement: The interaction of osteoblasts and osteoclasts with cells of the immune system has been suggested as a contributing factor in the development of osteoporoses. Evidence from studies in rodents suggests that $\mathrm{T}$ cells play a significant role in bone loss following estrogen deficiency. The goal of this study was to investigate whether the lack of functional $\mathrm{T}$ cells in nude rats prevents bone loss induced by Castration (Ctx) or Ovariectomy (Ovx). Approach: A pilot study was done to establish the immune phenotype of immunodeficient (NU) and immuno-competent $\mathrm{CD}$ rats using flow cytometry analysis of lymphocyte subsets. The main study included the following age-matched study groups: Males: CD Sham, CD Ctx, NU Sham and NU Ctx and Females: CD Sham, CD Ovx, NU Sham and NU Ovx. Bone mass, structure and BMD were assessed on long bones by microCT and strength by 3-point bending method. Results: Flow cytometry data showed that normal CD rats have significantly higher values for $\mathrm{NKT}, \mathrm{T}, \mathrm{CD} 8^{+}, \mathrm{CD}^{+}$and $\mathrm{CD} 25^{+}$cells relative to nudes, but also emphasize existing heterogeneity in lymphocyte subpopulation between different strains of immunodeficient rats. Deprivation of sex steroids caused only moderate loss of cancellous bone in NU rats relative to normal controls. Conclusion: Even though immunodeficiency does not provide complete protection from bone loss, regulation of bone metabolism by immune system prevents excessive deterioration of bone mass and structure seen in normal rats after Ctx and Ovx. This work supports concept that modulators of immune system could be welcomed addition to standard antiresorptive and anabolic therapies to treat osteoporoses of various etiologies.
\end{abstract}

Key words: Immunodeficient rats, ovariectomy, castration, bone structure, bone strength

\section{INTRODUCTION}

Osteoporosis is a heterogeneous disease that is characterized by loss of bone mass, impaired structural integrity and decreased Bone Mineral Density (BMD) resulting in a higher propensity to skeletal fractures (Kanis et al., 2002). Research on new drugs for prevention or treatment of osteoporosis is carried out in diverse animal models before being tested in the clinical situation. Among these models the skeleton of the laboratory rat has been studied most extensively and although there are some differences between the human and rat skeleton, rat remains the preferred species of most scientists for bone research (Kalu, 1991; Lelovas et al., 2008). Since 1994, the US Food and Drug Administration (FDA) have required testing of new drugs for prevention or treatment of osteoporosis in both the rat model and an additional well-validated large animal model (Thompson et al., 1995). Mouse models in bone research are used primarily for manipulation of the genome. Intense interest in transgenic animals over the past two decades has resulted in strains of mice with altered bone and marrow function. In addition, the existence of readily available recombinant murine cytokines supported utilization of transgenic mouse models as the logical starting point to research effect of genomic manipulation on bone physiology. Both mouse and rat models have significantly contributed to our understanding of bone physiology and pathology and have yielded research data that contributed to development of novel medicines and therapeutic approaches.

Athymic nude mice (Guise and Mundy, 1998; Renz et al., 1996; Zhau et al., 2000) and to a lesser extent nude rats (Andersen et al., 2003; Bagi et al., 2008; Schwinzer et al., 1987) have often been used to create orthotopic models for oncology and allograft rejection studies thus allowing research on human tissue physiology in living animals. Athymic nude rats

Corresponding Author:Cedo M. Bagi, Global Science and Technology PGRD, Pfizer Inc Eastern Point Road 8118-B3 Groton, CT 06340 Tel : (860)-715-6465 Fax: (860)-715-3577 
resemble nude mice; i.e., they lack a normal thymus and they are largely deficient in functionally mature $\mathrm{T}$ cells, lack of which leads to severe defects in T-cellmediated immune responses (Festing et al., 1978). With advanced age (12 months and older) nude rats develop T-like cells expressing CD3 and T-Cell Receptor (TCR). Even though the phenotype of these T-like cells in peripheral lymphatic tissue resembles that of normal $\mathrm{CD}^{+}$or $\mathrm{CD}^{+} \mathrm{T}$ cells, $\mathrm{T}$-like cells lack alloreactivity in vivo and their TCR repertoire is more of an oligoclonal nature (Sarawar et al., 1991; Schwinzer et al., 1987). Contribution of T-like cells to allograft rejection in Tcell-reconstituted rats is therefore questionable and their role in innate immune responses still remains unsolved (Rolstad, 2001). Aside from the T-cell phenotype, maturation of the leukocytes, number of granulocytes, erythrocytes, monocytes/macrophages, B cells and Natural Killer (NK) cells of nude rats is comparable to values reported for normal syngeneic rats (Benestad et al., 1989).

$\mathrm{T}$ cells originate in thymus after signaling events drive precursors from the hematopoietic stem cell pool in bone marrow to migrate and seed the thymus (Goldring, 2003). Over time the thymus undergoes agerelated atrophy that coincides with change in serum levels of sex steroids and occurrence of osteoporosis. Interaction of bone forming and bone resorbing cells and cells of the immune system has been recognized as an important factor that may contribute to development of osteoporoses of various etiologies (Cenci et al., 2003; Raisz, 2005). Recent evidence from studies in animal models suggests that $\mathrm{T}$ cells play significant role in bone loss following estrogen deficiency. Proposed mechanisms of bone-resorption driven remodeling process implicates among other factors enhanced production of TNF-alpha (Roggia et al., 2001; Schwarz and Bhandoola, 2004) and increased production of osteoclastogenic cytokines such as IL-7 by activated T cells (Pacifici, 2008; Weitzmann et al., 2000).

The overarching goal of this study was to establish if immunodeficiency (lack of functional $\mathrm{T}$ cells) in rats prevents bone loss following surgical ablation of sex steroids, an event that was described for nude mice (Pacifici, 2008). Prior to main study, a pilot study aimed to determine immune phenotype of nude rats form two sources was done and data compared to normal Sprague-Dawley rats. In the main study, aged matched immunocompetent rats were used as positive control since bone loss following estrogen or testosterone ablation in normal rats and mice is well documented (Bellido et al., 1995; Lelovas et al., 2008; Vanderschueren et al., 2004).

\section{MATERIAL AND METHODS}

Determination of immunologic parameters in normal and immunodeficient rats:

Animals: Nude male rats, 8 weeks old were obtained from Charles River (Fall River, MA) designation (Crl:NIH-Foxn1rnu) or from Taconic (Germantown, NY) designation (NTac: NIH-Whn). Normal, 8 week old CD rats, designation [Crl: CD (SD)] from Charles River were included for comparison in immunophenotyping experiments. The rats were maintained in an Association for Assessment and Accreditation of Laboratory Animal Care International (AAALAC) accredited research facility. All animal procedures were approved by the Institutional Animal Care and Use Committee (IACUC) and conformed to the "Guide for the Care and use of Laboratory Animals". Rats were pair housed in polycarbonate micro-isolator cages lined with autoclaved bedding. Autoclaved Reverse Osmosis (RO) water and autoclaved standard rat chow were provided ad libitum.

Immunophenotyping: Blood was collected in EDTA by jugular bleed and kept at room temperature until labeled with appropriate antibodies. A multi-cocktail four-color immunophenotyping strategy was used to enumerate the relative percentage of lymphocyte subpopulations of mononuclear leukocytes. Peripheral blood leukocytes were labeled using a whole blood lysis method. Briefly, $100 \mu \mathrm{L}$ of whole blood was aliquoted per tube per test and incubated for $30 \mathrm{~min}$ at room temperature protected from light. Following incubation, the red blood cells were lysed using BD FACSTM Lysing Solution (BD Biosciences, Franklin Lakes, NJ) and washed with phosphate buffered saline. Samples were immediately acquired using a BD Biosciences FACSCalibur flow cytometer.

Flow Cytometer Instrument Settings: An argon-ion laser (488 nm excitation) was used for FITC, PE and PerCP fluorophores. FITC (green fluorescence) was collected in Fluorescence detector 1 (FL1530/30 bandpass filter). PE (orange fluorescence) was collected in Fluorescence detector 2 (FL2585/42 bandpass filter). A red-diode laser (635 nm excitation) was used for APC measurement in FL3 (red fluorescence; 661/16 band-pass filter). Lymphoid cells were selected by a light scatter gating (forward vs. side scatter), while myeloid cells positive for OX41 were excluded from the analysis by Boolean gating.

Antibodies: Biotin conjugated mouse monoclonal [OX41] to SIRP- $\alpha$ (Cat. No. ab33987, Abcam Inc., Cambridge, MA) was used in conjunction with 
Streptavidin PerCP (Cat. No. 554064; BD Biosciences, Franklin Lakes, NJ) to identify myeloid lineage cells such as macrophages, monocytes, granulocytes and dendritic cells. This antibody pair was included with each lymphocyte-specific cocktail. The three lymphocyte-specific antibody cocktails used for phenotypic analysis included the Rat T/B/NK Cell Cocktail, Rat $\mathrm{T}$ Lymphocyte Cocktail and Rat Activated Lymphocyte Cocktail (558495, 558493, 558494 respectively; BD Biosciences). Antibodies present in the T/B/NK Cocktail include CD3-APC (Tcells), CD45Ra-FITC (B-cells) and CD161a-PE (NK cells). The T Lymphocyte Cocktail contains CD4-PE (Helper T-cells), CD8a FITC (Cytotoxic/Supressor Tcells) and CD3-APC (all T-cells). The antibody cocktail specific for Activated T Lymphocytes consists of CD3-APC (all T cells), CD25-PE (Lymphoblasts and Dendritic cells) and RT1B-FITC (MHC Class II expressing cells). Fluorescence compensation settings were established using the Rat Compensation Set kit (558517) and the Rat Activation Compensation Set kit (558512, BD Biosciences). Each experiment consisted of six animals per condition in addition to control cells from adult normal rats. All three antibody cocktails were used to characterize the lymphocyte subset phenotype of each animal. Variability between tubes was determined by comparing the CD3 positive cell population independently identified with each of the three antibody cocktails. Results were analyzed using student's unpaired T-test and/or ANOVA with a confidence interval of $5 \%$.

\section{Determination of bone metabolism following castration or ovariectomy in normal and immunodeficient rats:}

Animals: Experiments were carried out in male and female immuno-competent Sprague-Dawley rats and age and sex matched immuno-deficient rats from Taconic, since results from the pilot studies showed that Taconic nudes exhibit significantly less $T$ and NKT cells relative to $\mathrm{CR}$ nudes. The rats were either Castrated (Ctx), Ovariectomized (Ovx), or Sham operated (Sham) at Taconic (Germantown, NY) when 11 weeks old. Rats were shipped to Pfizer and were maintained according to the NIH standards established in the "Guide for the Care and use of Laboratory Animals". Rats were acclimatized for one week before start of the experiment and were single-housed in polycarbonate cages in a room maintained at $23 \pm 1^{\circ} \mathrm{C}$, $55 \pm 5 \%$ humidity with a 12 -h light/dark cycle; water and standard rat chow containing $0.80 \mathrm{Ca}, 0.60$ $\mathrm{P}$ and $2.2 \mathrm{IU} \mathrm{gm}^{-1}$ of vitamin $\mathrm{D}$ were provided ad libitum. Body weights were recorded once per week throughout the study.
Study design: Upon arrival at Pfizer rats were assigned to the following groups; Males: Group 1: SD Sham, Group 2: SD Ctx, Group 3: NU Sham and Group 4. NU Ctx and Females: Group 5: SD Sham, Group 6: SD Ovx, Group 7: NU Sham and Group 8: NU Ovx. There were 10 rats in each experimental group. The experiment was carried out for 12 weeks. Serum from all rats was collected at week 0 , week 6 and week 12 to measure serum levels of estrogen or testosterone and to assess change in biomarkers of bone metabolism. Cancellous bone assessment was also performed at the same time points $(0,6$ and 12 weeks) utilizing in vivo microCT system. Rats were sacrificed at the end of the study by $\mathrm{CO}_{2}$ inhalation; femurs and tibias were dissected and either snap-frozen in liquid $\mathrm{N}_{2}$ and stored at $-80^{\circ} \mathrm{C}$ for radiological analyses and mechanical testing or fixed in $10 \%$ formalin for histological analyses.

Serum chemistry and bone biomarkers: Blood samples were obtained 2, 8 and 13 weeks following surgeries. At each time point, $0.5 \mathrm{~mL}$ of blood was collected by jugular bleed; animals were lightly anesthetized during the bleed procedure with isoflurane. Determination of serum chemistry parameters was done using a Hitachi 917 auto analyzer (Roche, Indianapolis, IN); the standard core chemistry panel included: Aspartate Aminotransferase (AST), Alanine Aminotransferase (ALT), alkaline phosphatase, Blood Urea Nitrogen (BUN), glucose, cholesterol, bilirubin, total protein, albumin, globulin, sodium, phosphorus and chloride. Commercially available ELISA kits were utilized for determination of serum biomarkers: osteocalcin (OC; Nordic Bioscience, Denmark) Nterminal propeptide of type 1 procollagen (PINP) (PINP; Immunodiagnostic Systems, Fountain Hills, AZ) and specific epitope of collagen type 1 alpha 1 (CTX; Nordic Bioscience, Denmark). Serum estrogen or testosterone was also evaluated to confirm successful Ctx or Ovx surgery using Coat-A-Count testosterone and estradiol kits (Siemens Medical Solutions Diagnostics, New York, NY).

Micro-Computed Tomography (microCT): In vivo microCT analysis was performed using a Viva $\mu \mathrm{CT}$ $40^{\circledR}$ computed tomography system (Scanco Medical, Bassersdorf, Switzerland). Evaluation of bone structure was performed on rats $0,1.5,6$ and 12 weeks following surgeries. The rats were maintained on $2.5 \%$ isoflurane anesthesia for the duration of the scan utilizing an IMPAC6 (VetEquip Inc., Pleasanton, CA) anesthesia system. Animal was laid on its back in scanner bed with right leg extended distally and foot secured by leg holder. Care was taken to avoid unnatural strain on the 
joints. The proximal tibial metaphysis containing secondary spongiosa was identified as scan area of interest. Samples were scanned at high resolution with a source energy $\mathrm{kVp}$ of 70 and $\mathrm{mA}$ of 85 . Sample scan time was 10 minutes with a $2.5 \mathrm{~mm}$ scan area. CT images were reconstructed in $1024 \times 1024$-pixel matrices and stored in 3-D arrays. Upon completion, rats were allowed to recover in their home cages. 2-D and 3-D analysis was performed on cancellous bone compartment with a Region of Interest (ROI) manually defined to eliminate sub-cortical bone areas. A ROI for the metaphysis was drawn on 238 slices from 1.5-5.5 $\mathrm{mm}$ distal to the growth plate and defined to eliminate cortical bone.

Ex vivo microCT analysis was performed on distal femoral metaphyses for cancellous bone and on femoral mid-shaft (dyaphysis) for cortical bone using a viva $\mu \mathrm{CT}-40^{\circledR}$ computed tomography system (Scanco Medical, Bassersdorf, Switzerland) (Hanson and Bagi, 2004). For scanning, the distal femur sample was oriented horizontally in a $16.5 \mathrm{~mm}$ sample holder with the epiphyseal head facing outward. A control file, or measurement protocol, was created to define scanning parameters such as source energy, sample size and image resolution desired. Parameters selected for this study include a source voltage of $55 \mathrm{kV}$ and $\mathrm{I}(\mu \mathrm{A})$ of 109 to obtain the best contrast between bone and soft tissues. The sample area selected for three-dimensional structural analysis of cancellous bone was a $2.0 \mathrm{~mm}$ length of the metaphyseal secondary spongiosa, originating $0.5 \mathrm{~mm}$ below the epiphyseal growth plate and extending cranially. The following cancellous bone parameters were measured in both in vivo and ex vivo settings: Tissue Volume (TV), Bone Volume (BV), Bone Surface (BS), Bone Volume/Tissue Volume (BV/TV), Bone Surface/Bone Volume (BS/BV), Trabecular Number (Tb.N), Trabecular Thickness (Tb.Th), Trabecular Separation (Tb.Sp), Connective Density (Conn.D), SMI index (SMI) and Bone Mineral Density (BMD).

Cortical bone parameters were evaluated by microCT using method described earlier (Bagi et al., 2006). In brief, the CT images of the cortical bone were obtained approximately $1.5 \mathrm{~cm}$ proximal from distal end of the femur. Sample measurement (scan) was performed on the region using medium resolution settings. Each scan yielded an image data set of 25 $1024 \times 10242 \mathrm{D}$ axial slices through the mid-shaft region of the femur. The calculation was performed on 25 slices $(1$ slice $=10.5 \mu \mathrm{m})$, using the average for the final calculation. Total Area (TA) was calculated by counting all voxels within the counter, Bone Area (BA) by counting all voxels that were segmented as bone and bone Marrow Area (MA) was calculated as TA-BA. The outer and inner perimeter of the cortical mid-shaft was determined by a 3D triangulation of the Bone Surface (BS) of the 25 slices and cortical thickness was calculated using formula $\mathrm{C}$. Th $=1 / 2 * \mathrm{BS} / \mathrm{BV}$. In 2D analyses, the average area Moment Of Inertia (MOI) was calculated in $\mathrm{x}$ and $\mathrm{y}$ direction as well as the polar moment of inertia $\left(\mathrm{I}_{\mathrm{P}}\right)$. An Eigen-value analysis of the MOI tensor gave the principal directions and minimal and maximal I values $\left(\mathrm{I}_{\mathrm{MIN}}\right.$ and $\left.\mathrm{I}_{\mathrm{MAX}}\right)$. The moment of inertia calculations were performed in 2D mode, thus it was assumed that the bones were aligned with the axis of the scanner.

Mechanical testing: Femurs were mechanically tested with a load-to-failure three-point bending method. Femurs, carefully cleaned of soft tissues, were positioned cranial side up across the lower contacts of a three-point bending rig on a Bose Electro force 3300 series micromechanical testing machine (Bose Corporation; EnduraTEC Systems Group, Minnetonka, $\mathrm{MN})$. The lower contacts had a span width of $10.0 \mathrm{~mm}$ and the upper contact was centered between the lower contacts. The bone was broken in three-point bending using a crosshead speed of $0.5 \mathrm{~mm} \mathrm{sec}{ }^{-1}$. During testing, force and displacement data were collected every 0.05 seconds using WinTest software. Five parameters were determined from the stress-strain and force-elongation curves: Maximal load $(\mathrm{N})$, Toughness $\left(\mathrm{mJ} \mathrm{mm} \mathrm{mm}^{-3}\right.$, Pre and Post-yield displacement $(\mathrm{mm})$, Energy to failure $\left(\mathrm{N} \mathrm{mm}^{-1}\right)$ and modulus of elasticity (kPa) (Ritchie et al., 2008). Force versus displacement curves were visually inspected and maximal load (N) was recorded.

Statistical analysis: Data from biochemical bone measurement analyses are presented as Mean \pm SD. Statistical analysis of the data was performed by unpaired Student's t-test and repeated measures ANOVA using StatView software (SAS Institute Inc., Gary, NC, version 5.0.1). Differences were considered to be statistically significant when a p-value $<0.05$ was found.

\section{RESULTS}

Immunologic parameters in normal and immunodeficient rats: The lymphocyte subpopulations in normal and nude rats were identified 
Table 1: Shows lymphocyte subset results analyzed by flow cytometry in Charles River CD normal rats, Charles River nudes and Taconic source nude rats. The table also depicts distribution of $\mathrm{T}\left(\mathrm{CD}^{+}\right)$cells in Charles River $\mathrm{CD}$ normal rats, Charles River nudes and Taconic source nude rats. $\mathrm{T}$ cells were separated as cytotoxic $\mathrm{CD} 8 \mathrm{a}^{+} \mathrm{T}$ cells or helper $\mathrm{CD} 4^{+} \mathrm{T}$ cells. Activated $\mathrm{T}$ cell population was further defined as $\mathrm{CD} 25^{+}$lymphoblasts and dendritic cells or as $\mathrm{RT} 1 \mathrm{~B}^{+}$MHC Class II expressing cells

\begin{tabular}{|c|c|c|c|c|}
\hline \multirow[b]{2}{*}{ Rats } & \multicolumn{4}{|c|}{ Lymphocyte subpopulation } \\
\hline & B (\%) & $\mathrm{T} \mathrm{CD3}^{+}(\%)$ & NK $(\%)$ & NKT (\%) \\
\hline CR CD normal & $40.22 \pm 5.28^{\mathrm{a}}$ & $46.63 \pm 2.60^{\mathrm{a}}$ & $6.93 \pm 2.81^{\mathrm{a}}$ & $2.84 \pm 0.59^{\mathrm{a}}$ \\
\hline CR nudes & $58.03 \pm 5.43^{\mathrm{b}}$ & $29.05 \pm 2.12^{\mathrm{b}}$ & $26.61 \pm 1.39$ & $7.10 \pm 2.50^{\mathrm{b}}$ \\
\hline \multirow[t]{2}{*}{ Taconic nudes } & $71.24 \pm 2.74$ & $0.34 \pm 0.28$ & $30.12 \pm 4.97$ & $0.71 \pm 1.24$ \\
\hline & & & Activated T Ce & \\
\hline Rats & Cytotoxic CD8a $^{+}(\%)$ & Helper $\mathrm{CD4}^{+}(\%)$ & $\mathrm{CD}^{+}{ }^{+}(\%)$ & RT1B $^{+}(\%)$ \\
\hline CR CD normal & $15.39 \pm 1.05^{\mathrm{a}}$ & $31.13 \pm 2.07^{\mathrm{a}}$ & $2.88 \pm 0.19^{\mathrm{a}}$ & $1.51 \pm 0.32^{\mathrm{a}}$ \\
\hline CR nudes & $8.41 \pm 2.34^{\mathrm{b}}$ & $0.74 \pm 1.11$ & $0.11 \pm 0.08$ & $2.54 \pm 1.29^{\mathrm{b}}$ \\
\hline Taconic nudes & $0.81 \pm 1.25$ & $0.38 \pm 0.37$ & $0.11 \pm 0.16$ & $0.63 \pm 0.39$ \\
\hline
\end{tabular}

The differences between CR CD normal rats and CR or Taconic nude rats are statistically significant at ${ }^{\mathrm{a}}: \mathrm{p}<0.05$. The differences between $\mathrm{CR}$ nudes and Taconic nude rats are statistically significant at ${ }^{\mathrm{b}}: \mathrm{p}<0.05$.

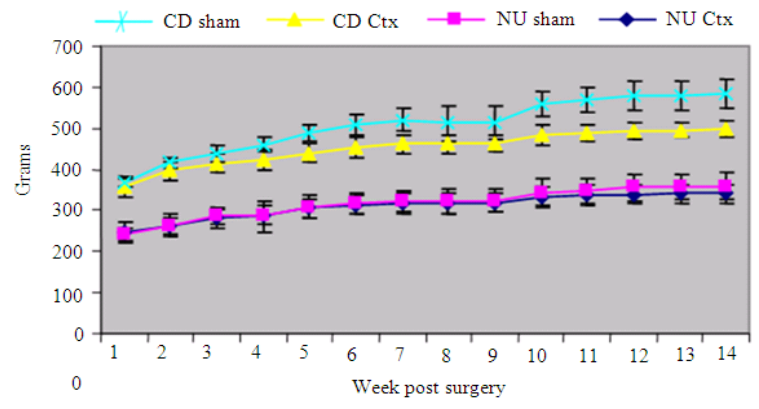

(A)

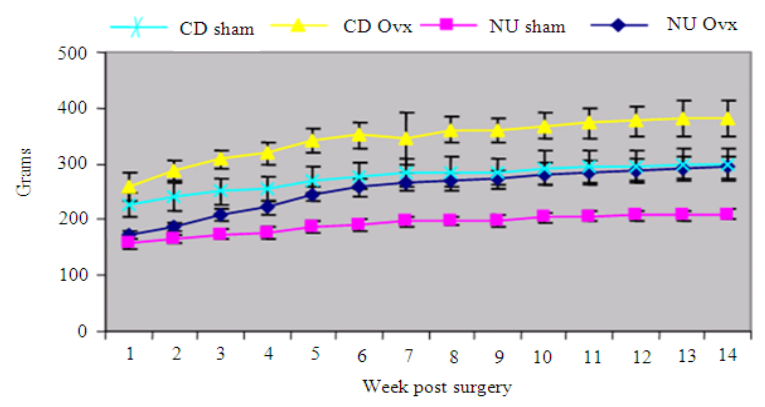

(B)

Fig. 1: Shows change in body weight in male (1A) and female (1B) rats from all experimental groups during the entire experimental period. All data were expressed as mean $\pm \mathrm{SD} ; \mathrm{n}=10$ rats/group

by their unique antigen binding cell surface receptors. The following populations of lymphocytes were identified: $\mathrm{B}$ cells, two primary types of $\mathrm{T}$ cells; cytotoxic $\mathrm{CD} 8 \mathrm{a}^{+} \mathrm{T}$ cells and helper, $\mathrm{CD} 4^{+} \mathrm{T}$ cells, the Natural Killer (NK) cells and a small population of NKT cells that was positive for both the NK and T markers. The activated $\mathrm{T}$ cell population was further defined as $\mathrm{CD} 25^{+}$lymphoblasts and dendritic cells or $\mathrm{RT} \mathrm{B}^{+}$MHC Class II expressing cells (Table 1).
Flow cytometry data have clearly demonstrated that normal CD rats have significantly higher number of $\mathrm{T}$ lymphocytes relative to nude rats regardless of their source and that values for $\mathrm{CD} 8^{+}, \mathrm{CD}^{+}$and $\mathrm{CD} 25^{+}$ markers are significantly higher in normal relative to either strain of homozygote nude rats (Table 1). Both strains of homozygote nudes have higher B and NK cell values compared to normal $C D$ rats. The two tested strains of nudes also show some differences; CR source nudes have significantly higher NKT, T, CD8 $\mathrm{a}^{+}$and $\mathrm{RT}_{1}{ }^{+}$markers relative to nudes obtained from Taconic, while Taconic source nudes have higher number of B lymphocytes compared to CR nudes. Experimental results were confirmed in a separate experiment with a second group of rats of the same age.

Body weight: All animals regardless of their immune status successfully completed the study as scheduled with no demonstration of adverse clinical signs. Normal male and female rats were larger in size and heavier compared their immunodeficient counterparts (Fig. 1A and B). After initial gain in body weight during the first 6 weeks of the study all rats reached a plateau and their body weighs remained stable throughout the second half of the experiment. Castrated normal rats were slightly lighter compared to sham controls, while there were no significant differences in body weight between sham and castrated nude males. Ovariectomy resulted in body weight gain in both normal and nude females (Fig. 1A and B).

Serum assays: Serum levels of testosterone or estrogen confirmed success of surgery. There were no significant difference between normal sham and nude sham rats in serum testosterone or estrogen levels 
Am. Med. J. 1 (1): 59-70, 2010

Table 2: Shows serum levels of testosterone or estrogen, OC, PINp and CTX at the end of 12 week time-point. All data were expressed as mean $\pm \mathrm{SD} ; \mathrm{n}=10 \mathrm{rats} /$ group

\begin{tabular}{lclll}
\hline Males & $\begin{array}{l}\text { Testosterone } \\
\left(\mathrm{ng} \mathrm{dL}^{-1}\right)\end{array}$ & $\begin{array}{l}\text { OC } \\
\left(\mathrm{ng} \mathrm{ml}^{-1}\right)\end{array}$ & $\begin{array}{l}\text { PINp } \\
\left(\mathrm{ng} \mathrm{ml}^{-1}\right)\end{array}$ & $\begin{array}{l}\text { CTX } \\
\left(\mathrm{ng} \mathrm{ml}^{-1}\right)\end{array}$ \\
\hline Group 1: CD Sham & $72.1 \pm 25.4^{\mathrm{a}}$ & $272.98 \pm 40.66$ & $22.59 \pm 3.50$ & $32.36 \pm 6.77$ \\
Group 2: CD Ctx & $1.3 \pm 1.30$ & $286.02 \pm 30.59$ & $14.15 \pm 3.23$ & $33.86 \pm 15.93$ \\
Group 3: NU Sham & $83.7 \pm 36.2^{\mathrm{a}}$ & $272.92 \pm 20.55$ & $21.68 \pm 4.74$ & $43.29 \pm 18.17$ \\
Group 4: NU Ctx & $2.2 \pm 1.20$ & $283.03 \pm 49.76$ & $16.21 \pm 2.19$ & $50.18 \pm 24.74$ \\
Females & Estradiol & OC & PINp & CTX \\
Group 5: CD Sham & $14.8 \pm 6.4^{\mathrm{a}}$ & $232.56 \pm 37.73$ & $16.18 \pm 3.02$ & $40.27 \pm 16.21$ \\
Group 6: CD Ovx & $4.3 \pm 2.0$ & $299.99 \pm 35.41$ & $15.49 \pm 4.32$ & $49.95 \pm 20.58$ \\
Group 7: NU Sham & $19.5 \pm 8.9^{\mathrm{a}}$ & $242.19 \pm 14.48$ & $16.10 \pm 1.37$ & $38.85 \pm 10.46$ \\
Group 8: NU Ovx & $2.7 \pm 1.1$ & $288.93 \pm 25.13$ & $51.14 \pm 22.45$ \\
\hline
\end{tabular}

The differences between CD Sham and CD Ctx and/or Ovx or between NU Sham and NU Ctx and/or Ovx are statistically significant at ${ }^{\mathrm{a}}$ : $\mathrm{p}<0.01$

(Table 2). At the end of study serum biomarkers of bone metabolism were similar in all groups of male and female rats regardless of their immune status or serum levels of sex steroids suggesting that 12 weeks after surgery bone metabolism was stable and that rats probably reached the steady state status in both bone modeling (growth) and bone remodeling. Castrated normal and nude males exhibited somewhat decreased levels of PINp at the end of study period, but noted difference did not reach statistical significance at that time point. Ovx normal and nude females still had elevated osteocalcin and CTX values at this time-point, yet the difference was not statistically significant (Table 2). Serum was analyzed at the end of study for a standard core chemistry panel with no differences observed between experimental groups (data not shown).

Bone metabolism following Ctx or Ovx in normal and immunodeficient rats: In vivo microCT scans performed at proximal tibial metaphysis showed similar cancellous bone structure of secondary spongiosa between normal and immunodeficient sham-operated male rats at 0 time point of the study. As the rats matured over time, both $\mathrm{CD}$ and nude males improved $\mathrm{BV}$, trabecular number, trabecular thickness, BMD and displayed higher connectivity of trabecular network. However, NU sham operated males displayed significantly higher trabecular number, but not thickness relative to age matched $\mathrm{CD}$ rats (Table 3). Castration resulted in loss of bone volume, loss of trabecular number, increase in trabecular separation and impaired connectivity in both normal and nude rats. However, nude males seems to be better protected from bone loss induced by castration since \% change in trabecular number over 12 week period was $47 \%$ in nudes compared to $68 \%$ recorded for $\mathrm{CD}$ males. As a result, \% change in trabecular separation in CD castrated males was approximately four-times higher relative to castrated nude rats. Percent increase in trabecular thickness parameter was higher in both $\mathrm{CD}$ and NU castrated rats compared to sham $\mathrm{CD}$ and $\mathrm{NU}$ rats. The BMD parameter was comparable in all males regardless of their immune status and surgery (Table 3 ).

Micro-CT analysis performed at proximal tibial metaphysis in female rats reviled that NU females increased trabecular number and bone volume in the region of secondary spongiosa significantly more than age-matched CD shams (Table 4). The increase in trabecular thickness was similar in both $\mathrm{CD}$ and NU sham females. As a result, NU sham females showed significantly reduced trabecular separation and improved connectivity compared to aged matched CD females. Nude female rats exhibited similar \% increase in BMD to normal controls. Ovariectomy resulted in loss of bone volume, loss of trabecular number, increased trabecular separation and impaired connectivity in both $\mathrm{CD}$ and NU female rats. However, nude females seems to be better protected from bone loss induced by Ovx since percent change in trabecular number was only $57 \%$ in NU relative to $82 \%$ in CD females. As a result, trabecular separation parameter in nude Ovx females was approximately five-times lowers relative to Ovx-ed CD rats. The BMD parameter was comparable in both groups of Ovx rats (Table 4).

Ex vivo micro-CT analysis performed 12 weeks post surgery at distal femoral metaphysis and cortical mid-shaft showed some differences between $\mathrm{CD}$ and NU male rats. Namely, NU males exhibited higher trabecular number, improved connectivity and reduced trabecular separation compared to normal $\mathrm{CD}$ males (Table 5). On the other hand, $\mathrm{CD}$ rats have larger bones relative to $\mathrm{NU}$ rats and $\mathrm{CD}$ shams exhibited higher numbers for all cortical bone parameters compared to NU shams with the only exception being BMD (Table 5, Fig. 2). Castration resulted in loss of 
Am. Med.J. 1 (1): 59-70, 2010

Table 3: Shows \% change in structural 3-dimensional cancellous bone parameters in male rats evaluated in vivo at proximal tibial metaphysis (secondary spongiosa) at various time-points post castration. Red arrow indicates \% increase and blue arrow \% decrease in measured parameters over time following Ctx; $\mathrm{n}=10$ rats/group

\begin{tabular}{|c|c|c|c|c|c|c|c|}
\hline \multirow{2}{*}{$\begin{array}{l}\text { Cancellous bone } \\
\text { parameter }\end{array}$} & \multirow{2}{*}{$\begin{array}{l}\text { Time } \\
\text { (week) }\end{array}$} & \multirow{2}{*}{$\begin{array}{l}\text { CD } \\
\text { Sham }\end{array}$} & \multirow{2}{*}{$\begin{array}{l}\text { Males } \\
\text { Ctx }\end{array}$} & \multirow[t]{2}{*}{$\begin{array}{l}\text { NU } \\
\text { Sham }\end{array}$} & \multirow[t]{2}{*}{$\begin{array}{l}\text { Males } \\
\text { Ctx }\end{array}$} & \multicolumn{2}{|c|}{$\begin{array}{l}\text { Significance } \\
\text { CD Vs. NU }\end{array}$} \\
\hline & & & & & & & \\
\hline$\overline{B V}$ & $0-1.5$ & $1.0 \mathrm{\nabla}$ & $20.8 \boldsymbol{\nabla},{ }^{b}$ & $0.6 \mathbf{\nabla}$ & $22.4 \mathbf{\nabla}$, & ns; & ns \\
\hline \multirow{3}{*}{ (\% change) } & $1.5-6$ & $3.1 \mathrm{\nabla}$ & $36.9 \boldsymbol{\nabla}$, & $2.5 \mathrm{~V}$ & $30.2 \boldsymbol{\nabla}, \mathrm{b}$ & ns; & ns \\
\hline & $6-12$ & $11.8 \boldsymbol{\Delta}$ & $39.6 \boldsymbol{\nabla}$ & $25.3 \boldsymbol{\Delta}$ & $1.3 \nabla, b$ & 0.05 & 0.001 \\
\hline & $0-12$ & $8.3 \boldsymbol{\Delta}$ & $69.8 \boldsymbol{\nabla}, \mathrm{b}$ & $22.2 \boldsymbol{\Delta}$ & $44.5 \nabla, b$ & 0.05 & 0.05 \\
\hline Tb.No & $0-1.5$ & $1.3 \mathbf{\nabla}$ & $16.1 \boldsymbol{\nabla}$, & $1.0 \boldsymbol{\nabla}$ & $21.7 \boldsymbol{\nabla}, \mathrm{b}$ & ns; & ns \\
\hline \multirow{3}{*}{ ( $\%$ change) } & $1.5-6$ & $4.1 \boldsymbol{\nabla}$ & $43.6 \boldsymbol{\nabla},{ }^{a}$ & $2.6 \boldsymbol{\nabla}$ & $34.5 \nabla, b$ & 0.05 & 0.05 \\
\hline & $6-12$ & $6.7 \boldsymbol{\Delta}$ & $34.0 \boldsymbol{\nabla}^{\mathrm{b}}$ & $18.8 \boldsymbol{\Delta}$ & $1.7 \nabla, b$ & 0.05 & 0.001 \\
\hline & $0-12$ & $7.5 \bar{\Delta}$ & $68.7 \mathbf{\nabla}$ & $15.7 \boldsymbol{\Delta}$ & $47.8 \nabla, b$ & 0.05 & $\mathrm{~ns}$ \\
\hline Tb.Th & $0-1.5$ & $1.2 \boldsymbol{\Delta}$ & $1.7 \boldsymbol{\Delta}, \mathrm{b}$ & $1.1 \boldsymbol{\Delta}$ & $1.5 \Delta \mathrm{c}^{\mathrm{b}}$ & ns; & ns \\
\hline \multirow[t]{3}{*}{ (\% change) } & $1.5-6$ & $7.3 \boldsymbol{\Delta}$ & $5.5 \Delta, \mathrm{b}$ & $2.9 \boldsymbol{\Delta}$ & $8.4 \boldsymbol{\Delta},{ }^{b}$ & 0.05 & ns \\
\hline & $6-12$ & $1.2 \bar{\Delta}$ & $9.8 \boldsymbol{\Delta}, \mathrm{b}$ & $4.9 \boldsymbol{\Delta}$ & $10.9 \boldsymbol{\Lambda}^{\mathrm{b}}$ & 0.05 & $\mathrm{~ns}$ \\
\hline & $0-12$ & $8.0 \boldsymbol{\Delta}$ & $17.8 \boldsymbol{\Lambda},{ }^{\mathrm{a}}$ & $8.3 \boldsymbol{\Delta}$ & $17.1 \boldsymbol{\Lambda},{ }^{a}$ & ns; & ns \\
\hline Tb.Sp & $0-1.5$ & $2.0 \boldsymbol{\Delta}$ & $22.9 \boldsymbol{\Delta},{ }^{b}$ & $3.1 \boldsymbol{\Delta}$ & $27.4 \boldsymbol{\Delta}, \mathrm{b}$ & ns; & ns \\
\hline \multirow[t]{3}{*}{ (\% change) } & $1.5-6$ & $7.4 \bar{\Delta}$ & $90.9 \boldsymbol{\Lambda},{ }^{\mathrm{a}}$ & $5.3 \Delta$ & $52.7 \boldsymbol{\Lambda}$, b & ns; & 0.05 \\
\hline & $6-12$ & $8.5 \boldsymbol{\nabla}$ & $59.2 \boldsymbol{\Delta},{ }^{\mathrm{b}}$ & $16.8 \boldsymbol{\nabla}$ & $0.2 \boldsymbol{\Delta},{ }^{b}$ & 0.05 & 0.001 \\
\hline & $0-12$ & $3.2 \boldsymbol{\nabla}$ & $374.1 \boldsymbol{\Delta},{ }^{b}$ & $21.2 \boldsymbol{\nabla}$ & $91.6 \boldsymbol{\Delta}, \mathrm{b}$ & 0.001 & 0.05 \\
\hline Conn.D & $0-1.5$ & $3.6 \boldsymbol{\nabla}$ & $35.5 \nabla \mathrm{b}$ & $2.2 \boldsymbol{\nabla}$ & $15.7 \boldsymbol{\nabla}, \mathrm{b}$ & ns; & 0.05 \\
\hline \multirow{3}{*}{ ( $\%$ change) } & $1.5-6$ & $6.2 \mathrm{~V}$ & $40.5 \boldsymbol{\nabla},{ }^{a}$ & $6.0 \mathrm{\nabla}$ & $48.0 \quad \nabla,{ }^{a}$ & ns; & $\mathrm{ns}$ \\
\hline & $6-12$ & $7.1 \boldsymbol{\Delta}$ & $41.0 \boldsymbol{\nabla}$ & $15.9 \boldsymbol{\Delta}$ & $8.7 \boldsymbol{\nabla}$ & 0.05 & 0.05 \\
\hline & $0-12$ & $9.4 \bar{\Delta}$ & $77.3 \mathbf{\nabla}, \mathrm{b}$ & $13.8 \overline{\boldsymbol{\Lambda}}$ & $64.3 \nabla$, & 0.05 & ns \\
\hline BMD & $0-1.5$ & $0.2 \boldsymbol{\Delta}$ & $0.7 \boldsymbol{\nabla},{ }^{\mathrm{a}}$ & $0.3 \boldsymbol{\Lambda}$ & $2.5 \nabla,{ }^{a}$ & ns; & ns \\
\hline \multirow[t]{3}{*}{ ( $\%$ change) } & $1.5-6$ & $1.6 \Delta$ & $1.9 \boldsymbol{\Delta}$ & $2.6 \Delta$ & $3.3 \boldsymbol{\Delta}$ & ns; & ns \\
\hline & $6-12$ & $2.2 \boldsymbol{\Delta}$ & $2.9 \boldsymbol{\Delta}$ & $2.1 \boldsymbol{\Delta}$ & $1.6 \boldsymbol{\Delta}$ & ns; & ns \\
\hline & $0-12$ & $3.9 \boldsymbol{\Delta}$ & $4.1 \boldsymbol{\Delta}$ & $4.7 \boldsymbol{\Delta}$ & $3.6 \boldsymbol{\Delta},{ }^{\mathrm{a}}$ & ns; & ns \\
\hline
\end{tabular}

The differences between CD Sham and CD Ctx or NU sham and NU Ctx are statistically significant at ${ }^{a} \mathrm{p}<0.05$ and ${ }^{\mathrm{b}} \mathrm{p}<0.005$. The statistical difference in bone parameters between CD Sham and NU sham or CD Ctx and NU Ctx is indicated in Significance column; ns = non significant.

Table 4: Shows \% change in structural 3-dimensional cancellous bone parameters in male rats evaluated in vivo at proximal tibial metaphysis (secondary spongiosa) at various time-points post ovariectomy. Red arrow indicates \% increase and blue arrow \% decrease in measured parameters over time following Ovx; $\mathrm{n}=10$ rats/group

\begin{tabular}{|c|c|c|c|c|c|c|c|}
\hline \multirow{2}{*}{$\begin{array}{l}\text { Cancellous Bone } \\
\text { Parameter }\end{array}$} & \multirow{2}{*}{$\begin{array}{l}\text { Time } \\
\text { (week) }\end{array}$} & $\mathrm{CD}$ & Males & $\mathrm{NU}$ & Females & \multicolumn{2}{|c|}{$\begin{array}{l}\text { Significance } \\
\text { CD vs. NU }\end{array}$} \\
\hline & & Sham & Ovx & Sham & Ovx & Sham & Ovx \\
\hline $\mathrm{BV}$ & $0-1.5$ & $1.1 \mathrm{\Delta}$ & $26.6 \nabla$ & $2.6 \boldsymbol{\Delta}$ & $16.9 \nabla, b$ & ns; & 0.05 \\
\hline \multirow[t]{3}{*}{ ( $\%$ change) } & $1.5-6$ & $11.7 \boldsymbol{\Delta}$ & $71.6 \nabla$ & $14.5 \overline{\boldsymbol{\Lambda}}$ & $51.0 \nabla$ & $\mathrm{ns}$ & 0.05 \\
\hline & $6-12$ & $0.6 \Delta$ & $31.1 \nabla$ & $38.3 \boldsymbol{\Delta}$ & $5.4 \nabla$ & 0.001 & 0.001 \\
\hline & $0-12$ & $11.4 \boldsymbol{\Delta}$ & $80.3 \nabla$, & $68.5 \boldsymbol{\Delta}$ & $53.6 \nabla$, & 0.001 & 0.05 \\
\hline Tb.No & $0-1.5$ & $0.3 \boldsymbol{\Delta}$ & $33.1 \nabla$, & $12.3 \boldsymbol{\Delta}$ & $25.3 \nabla$, & 0.001 & ns \\
\hline \multirow[t]{3}{*}{ ( $\%$ change) } & $1.5-6$ & $6.2 \boldsymbol{\Delta}$ & $72.1 \nabla$, & $28.7 \boldsymbol{\Delta}$ & $62.7 \nabla$, & 0.05 & ns \\
\hline & $6-12$ & $1.7 \boldsymbol{\Delta}$ & $35.5 \nabla$, & $22.6 \boldsymbol{\Delta}$ & $1.5 \nabla$ & 0.001 & 0.001 \\
\hline & $0-12$ & $0.4 \boldsymbol{\Delta}$ & $82.0 \nabla$, & $57.9 \boldsymbol{\Delta}$ & $64.2 \nabla, b$ & 0.001 & 0.05 \\
\hline Tb.Th & $0-1.5$ & $1.0 \boldsymbol{\Delta}$ & $2.2 \boldsymbol{\Delta},{ }^{a}$ & $0.3 \boldsymbol{\Lambda}$ & $0.1 \boldsymbol{\Lambda}$ & ns; & ns \\
\hline \multirow[t]{3}{*}{ ( $\%$ change) } & $1.5-6$ & $10.4 \boldsymbol{\Delta}$ & $12.3 \boldsymbol{\Delta}$ & $11.6 \boldsymbol{\Delta}$ & $0.2 \boldsymbol{\Delta},{ }^{b}$ & ns; & 0.001 \\
\hline & $6-12$ & $0.4 \boldsymbol{\Delta}$ & $0.5 \boldsymbol{\Delta}$ & $0.9 \boldsymbol{\Delta}$ & $8.2 \boldsymbol{\Delta},{ }^{b}$ & ns; & 0.05 \\
\hline & $0-12$ & $10.8 \boldsymbol{\Delta}$ & $11.7 \boldsymbol{\Delta}$ & $10.5 \boldsymbol{\Delta}$ & $8.3 \boldsymbol{\Delta}$ & ns; & ns \\
\hline Tb.Sp & $0-1.5$ & $2.3 \nabla$ & $46.5 \boldsymbol{\Delta}$, & $3.2 \overline{\boldsymbol{\nabla}}$ & $32.4 \boldsymbol{\Delta}$, & ns; & 0.001 \\
\hline \multirow[t]{3}{*}{ ( $\%$ change) } & $1.5-6$ & $7.8 \boldsymbol{\nabla}$ & $550.2 \boldsymbol{\Delta},{ }^{b}$ & $17.9 \boldsymbol{\nabla}$ & $297.0 \boldsymbol{\Delta}^{\mathrm{b}}$ & 0.05 & 0.05 \\
\hline & $6-12$ & $10.8 \nabla$ & $246.8 \boldsymbol{\Delta},{ }^{b}$ & $28.7 \boldsymbol{\nabla}$ & $0.8 \boldsymbol{\Lambda},{ }^{b}$ & 0.05 & 0.001 \\
\hline & $0-12$ & $14.3 \mathbf{V}$ & $1989.1 \boldsymbol{\Delta}$, & $48.6 \boldsymbol{\nabla}$ & $396.3 \boldsymbol{\Delta},{ }^{b}$ & 0.001 & 0.001 \\
\hline Conn.D & $0-1.5$ & $2.0 \boldsymbol{\Delta}$ & $45.6 \boldsymbol{\nabla}, \mathrm{b}$ & $13.4 \boldsymbol{\Delta}$ & $31.7 \boldsymbol{\nabla}, \mathrm{b}$ & 0.05 & ns \\
\hline \multirow{3}{*}{ ( $\%$ change) } & $1.5-6$ & $11.1 \boldsymbol{\Delta}$ & $82.8 \boldsymbol{\nabla},{ }^{b}$ & $48.8 \boldsymbol{\Delta}$ & $73.2 \boldsymbol{\nabla}, \mathrm{b}$ & 0.05 & ns \\
\hline & $6-12$ & $4.6 \boldsymbol{\Delta}$ & $34.9 \nabla$, & $28.7 \boldsymbol{\Lambda}$ & $17.1 \nabla$, & 0.05 & 0.05 \\
\hline & $0-12$ & $7.4 \boldsymbol{\Delta}$ & $93.9 \boldsymbol{\nabla}, \mathrm{b}$ & $91.4 \boldsymbol{\Lambda}$ & $85.0 \boldsymbol{\nabla}, \mathrm{b}$ & 0.001 & ns \\
\hline & $0-1.5$ & $0.2 \boldsymbol{\Delta}$ & $0.1 \boldsymbol{\nabla},{ }^{b}$ & $0.3 \boldsymbol{\Delta}$ & $1.1 \nabla^{b}$ & ns; & ns \\
\hline \multirow[t]{3}{*}{ ( $\%$ change) } & $1.5-6$ & $2.9 \boldsymbol{\Delta}$ & $0.2 \boldsymbol{\Delta}, \mathrm{b}$ & $2.0 \boldsymbol{\Delta}$ & $4.3 \Delta$ & ns; & ns \\
\hline & $6-12$ & $0.9 \boldsymbol{\Delta}$ & $1.0 \boldsymbol{\Delta},{ }^{b}$ & $2.2 \boldsymbol{\Delta}$ & $0.3 \boldsymbol{\nabla},{ }^{b}$ & ns; & ns \\
\hline & $0-12$ & $4.2 \boldsymbol{\Delta}$ & $1.0 \boldsymbol{\Delta}^{\mathrm{b}}$ & $4.3 \boldsymbol{\Delta}$ & $1.3 \boldsymbol{\Delta},{ }^{b}$ & ns; & $\mathrm{ns}$ \\
\hline
\end{tabular}

The differences between CD Sham and CD Ovx or NU sham and NU Ovx are statistically significant at ${ }^{\mathrm{a}}: \mathrm{p}<0.05$ and ${ }^{\mathrm{b}}: \mathrm{p}<0.005$; The statistical difference in bone parameters between CD Sham and NU sham or CD Ovx and NU Ovx is indicated in Significance column; ns = non significant 
Am. Med.J. 1 (1): 59-70, 2010

Table 5: Shows structural 3-dimensional cancellous bone parameters in male rats evaluated ex vivo at distal femoral metaphysis (secondary spongiosa) at the end of study conduct, 12 weeks post castration using Viva $\mu$ CT-40 ${ }^{\circledR}$ system. All data were expressed as mean $\pm \mathrm{SD}$; $\mathrm{n}$ $=10 \mathrm{rats} /$ group

\begin{tabular}{|c|c|c|c|c|c|c|}
\hline \multirow{2}{*}{$\begin{array}{l}\text { Cancellous bone } \\
\text { parameters }\end{array}$} & \multirow{2}{*}{\begin{tabular}{l} 
CD \\
\hdashline--- \\
Sham
\end{tabular}} & \multirow{2}{*}{$\begin{array}{l}\text { Males } \\
\text { Ctx }\end{array}$} & \multirow{2}{*}{\begin{tabular}{l} 
NU \\
\hdashline--- \\
Sham
\end{tabular}} & \multirow{2}{*}{$\begin{array}{l}\text { Males } \\
\text { Ctx }\end{array}$} & \multicolumn{2}{|c|}{$\begin{array}{l}\text { Significance } \\
\text { CD Vs. NU }\end{array}$} \\
\hline & & & & & Sham & $\mathrm{Ctx}$ \\
\hline $\mathrm{BV}\left(\mathrm{mm}^{3}\right)$ & $8.08 \pm 2.27^{\mathrm{c}}$ & $3.91 \pm 1.09$ & $8.17 \pm 1.35^{\mathrm{a}}$ & $6.85 \pm 1.07$ & ns; & 0.001 \\
\hline BV/TV (\%) & $30.6 \pm 7.4^{\mathrm{c}}$ & $17.8 \pm 4.500$ & $34.7 \pm 3.1^{\mathrm{a}}$ & $28.6 \pm 3.200$ & ns; & 0.01 \\
\hline Tb.N $\left(1 \mathrm{~mm}^{-1}\right)$ & $4.020 .86^{\mathrm{b}}$ & $2.52 \pm 0.53$ & $4.88 \pm 0.50^{\mathrm{a}}$ & $3.91 \pm 0.35$ & 0.05 & 0.01 \\
\hline Tb.Th $(\mu \mathrm{m})$ & $73.5 \pm 3.8^{b}$ & $67.7 \pm 4.900$ & $70.3 \pm 2.700$ & $72.7 \pm 3.100$ & $\mathrm{~ns}$ & ns \\
\hline Tb.Sp $(\mu \mathrm{m})$ & $193.2 \pm 63.7^{\mathrm{c}}$ & $356.4 \pm 83.80$ & $147.1 \pm 22.0^{\mathrm{a}}$ & $195.5 \pm 22.60$ & 0.05 & 0.01 \\
\hline Conn.D $\left(1 \mathrm{~mm}^{-3}\right)$ & $150.8 \pm 67.97^{\mathrm{b}}$ & $58.4 \pm 19.80$ & $222.0 \pm 4.52^{\mathrm{a}}$ & $140.3 \pm 28.75$ & 0.05 & 0.001 \\
\hline $\operatorname{BMD}\left(\mathrm{mg} \mathrm{cm}^{-2}\right)$ & $904.8 \pm 8.070$ & $907.1 \pm 8.550$ & $896.3 \pm 8.470$ & $902.9 \pm 7.070$ & ns; & ns \\
\hline $\mathrm{TV}\left(\mathrm{mm}^{3}\right)$ & $3.90 \pm 0.29^{b}$ & $3.31 \pm 0.36$ & $3.05 \pm 0.23$ & $2.92 \pm 0.15$ & 0.05 & 0.05 \\
\hline $\mathrm{BV}\left(\mathrm{mm}^{3}\right)$ & $1.94 \pm 0.14^{\mathrm{b}}$ & $1.65 \pm 0.14$ & $1.31 \pm 0.07$ & $1.29 \pm 0.06$ & 0.05 & 0.05 \\
\hline $\operatorname{MV}\left(\mathrm{mm}^{3}\right)$ & $1.96 \pm 0.21^{\mathrm{a}}$ & $1.66 \pm 0.25$ & $1.74 \pm 0.18$ & $1.62 \pm 0.12$ & 0.05 & ns \\
\hline $\mathrm{Th}(\mathrm{mm})$ & $0.71 \pm 0.03$ & $0.68 \pm 0.04$ & $0.55 \pm 0.02$ & $0.57 \pm 0.04$ & 0.01 & 0.05 \\
\hline $\mathrm{BMD}\left(\mathrm{mg} \mathrm{cm}^{-2}\right)$ & $1222.3 \pm 8.200$ & $1238.9 \pm 11.90$ & $1192.7 \pm 9.2^{\mathrm{b}}$ & $1198.9 \pm 7.100$ & $\mathrm{~ns}$ & ns \\
\hline CArea $\left(\mathrm{mm}^{-2}\right)$ & $8.02 \pm 0.58^{b}$ & $6.84 \pm 0.57$ & $5.41 \pm 0.28$ & $5.34 \pm 0.25$ & 0.01 & 0.05 \\
\hline $\mathrm{I}_{\mathrm{MIN}}\left(\mathrm{mm}^{4}\right)$ & $7.62 \pm 1.12^{\mathrm{b}}$ & $5.75 \pm 1.13$ & $4.47 \pm 0.54$ & $4.30 \pm 0.43$ & 0.01 & 0.05 \\
\hline $\mathrm{I}_{\mathrm{MAX}}\left(\mathrm{mm}^{4}\right)$ & $13.48 \pm 1.58^{\mathrm{b}}$ & $9.89 \pm 1.96$ & $7.61 \pm 1.11$ & $6.87 \pm 0.54$ & 0.01 & 0.05 \\
\hline $\mathrm{I}_{\mathrm{P}}\left(\mathrm{mm}^{4}\right)$ & $21.11 \pm 2.43^{\mathrm{b}}$ & $15.65 \pm 2.04$ & $12.08 \pm 1.61$ & $11.18 \pm 0.94$ & 0.001 & 0.05 \\
\hline $\mathrm{I}_{\mathrm{MAX}} / \mathrm{C}_{\mathrm{MAX}}\left(\mathrm{mm}^{3}\right)$ & $5.65 \pm 0.53^{\mathrm{b}}$ & $4.43 \pm 0.64$ & $3.68 \pm 0.40$ & $3.39 \pm 0.21$ & 0.01 & 0.05 \\
\hline
\end{tabular}

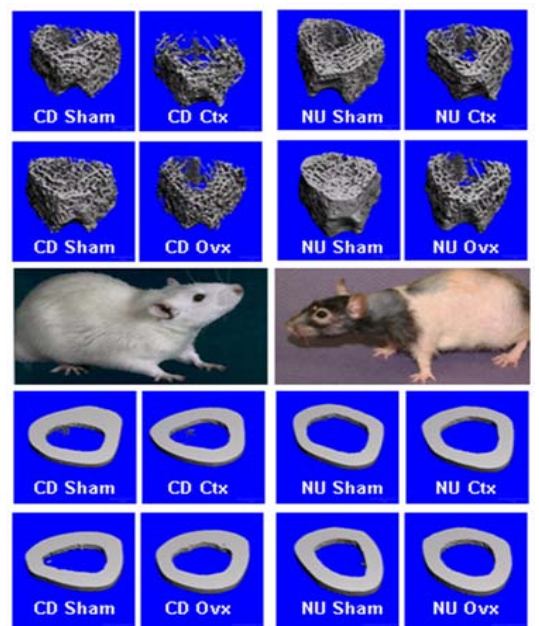

Fig. 2A: Shows 3D images of cancellous bone at distal femoral metaphysis and $2 \mathrm{~B}$ shows $3 \mathrm{D}$ crosssectional images of femoral dyaphysis obtained ex vivo by micro-CT at the end of study. Images depict difference in bone content between normal and immunodeficient animals, but also difference between sham and Ctx males or sham and Ovx female rats. Also, both sham nude males and females had more cancellous bone comparing to their normal counterparts and had lost less cancellous bone after $\mathrm{Ctx}$ or Ovx relative to normal rats. cancellous bone volume, trabecular number and connectivity in both CD and NU males, however, the impact of Ctx on cancellous bone mass and structure in NU rats was far smaller relative to impact observed in normal $\mathrm{CD}$ rats. In addition, cortical bone properties were reduced in CD rats but not in NU rats (Table 5, Fig. 2). Castrated NU rats exhibited higher cancellous bone parameters including $\mathrm{BV}, \mathrm{BV} / \mathrm{TV}, \mathrm{Tb} . \mathrm{N}$ and Conn.D compared to castrated $\mathrm{CD}$ rats, while $\mathrm{CD}$ rats showed higher numbers for cortical bone parameters relative to NU castrates. $\mathrm{CD}$ shams had stronger cortical bone compared to $\mathrm{CD}$ castrates, but also compared to NU shams. CD castrated rats had stronger cortical bone relative to NU castrates (Fig. 3).

Ex vivo micro-CT analysis performed 12 weeks post surgery at distal femoral metaphysis and cortical mid-shaft showed some differences between $C D$ and NU female rats. Namely, NU females exhibited higher trabecular number, improved connectivity and reduced trabecular separation compared to normal CD females (Table 6). On the other hand, $\mathrm{CD}$ females have larger bones relative to NU rats and $\mathrm{CD}$ shams exhibited higher numbers for all cortical bone parameters compared to NU shams with the only exception being BMD (Table 6). Ovariectomy resulted in loss of cancellous bone volume, decreased $\%$ of BV/TV, lower trabecular number and decreased connectivity in both $\mathrm{CD}$ and NU females, however the skeleton of NU females was less affected by Ovx than the skeleton of 
Am. Med.J. 1 (1): 59-70, 2010

Table 6: Shows structural 3-dimensional cancellous bone parameters in female rats evaluated ex vivo at distal femoral metaphysis (secondary spongiosa) at the end of study conduct, 12 weeks post castration using Viva $\mu$ CT-40 ${ }^{\circledR}$ system. All data were expressed as mean $\pm \mathrm{SD}$; $\mathrm{n}$ $=10 \mathrm{rats} /$ group

\begin{tabular}{|c|c|c|c|c|c|c|}
\hline \multirow{2}{*}{$\begin{array}{l}\text { Cancellous bone } \\
\text { parameters }\end{array}$} & \multirow{2}{*}{$\begin{array}{l}\text { CD } \\
\text { Sham }\end{array}$} & Females & \multirow{2}{*}{\begin{tabular}{l} 
NU \\
\hdashline Sham
\end{tabular}} & Females & \multicolumn{2}{|c|}{$\begin{array}{l}\text { Significance } \\
\text { CD vs. NU }\end{array}$} \\
\hline & & Ovx & & Ovx & Sham & Ovx \\
\hline $\mathrm{BV}\left(\mathrm{mm}^{3}\right)$ & $9.66 \pm 3.50^{\mathrm{c}}$ & $3.73 \pm 1.19$ & $10.49 \pm 0.96^{\mathrm{c}}$ & $5.73 \pm 0.77$ & $\mathrm{~ns}$ & 0.05 \\
\hline BV/TV $(\%)$ & $46.4 \pm 6.3^{\mathrm{d}}$ & $17.5 \pm 4.70$ & $60.4 \pm 4.5^{\mathrm{c}}$ & $30.7 \pm 3.80$ & 0.05 & 0.01 \\
\hline Tb.N $\left(1 \mathrm{~mm}^{-1}\right)$ & $5.49 \pm 0.52^{\mathrm{c}}$ & $2.68 \pm 0.59$ & $7.02 \pm 0.50^{\mathrm{c}}$ & $4.14 \pm 0.31$ & 0.05 & 0.05 \\
\hline Tb.Th $(\mu \mathrm{m})$ & $84.6 \pm 7.90$ & $74.5 \pm 4.30$ & $85.2 \pm 6.70$ & $72.6 \pm 3.30$ & $\mathrm{~ns}$ & ns \\
\hline Tb.Sp $(\mu \mathrm{m})$ & $104.5 \pm 34.3^{\mathrm{c}}$ & $337.9 \pm 92.4$ & $65.7 \pm 14.7^{\mathrm{c}}$ & $174.2 \pm 26.1$ & 0.05 & 0.01 \\
\hline Conn.D $\left(1 \mathrm{~mm}^{-3}\right)$ & $338.3 \pm 128.0^{\mathrm{c}}$ & $75.2 \pm 26.6$ & $531.9 \pm 52.7^{\mathrm{c}}$ & $166.9 \pm 28.5$ & 0.05 & 0.01 \\
\hline $\mathrm{BMD}\left(\mathrm{mg} \mathrm{cm}^{-2}\right)$ & $908.0 \pm 14.50$ & $905.2 \pm 12.1$ & $887.9 \pm 8.99$ & $898.6 \pm 4.30$ & ns; & ns \\
\hline $\mathrm{TV}\left(\mathrm{mm}^{3}\right)$ & $2.83 \pm 0.29$ & $2.79 \pm 0.26$ & $2.14 \pm 0.06^{\mathrm{c}}$ & $2.42 \pm 0.120$ & 0.05 & 0.05 \\
\hline $\mathrm{BV}\left(\mathrm{mm}^{3}\right)$ & $1.40 \pm 0.14$ & $1.38 \pm 0.11$ & $0.99 \pm 0.02$ & $1.14 \pm 0.05$ & 0.05 & 0.05 \\
\hline $\operatorname{MV}\left(\mathrm{mm}^{3}\right)$ & $1.43 \pm 0.16$ & $1.52 \pm 0.16$ & $1.15 \pm 0.05$ & $1.28 \pm 0.100$ & 0.05 & $\mathrm{~ns}$ \\
\hline $\mathrm{Th}(\mathrm{mm})$ & $0.56 \pm 0.05$ & $0.51 \pm 0.03$ & $0.49 \pm 0.03^{\mathrm{a}}$ & $0.43 \pm 0.020$ & $\mathrm{~ns}$ & 0.05 \\
\hline $\mathrm{BMD}\left(\mathrm{mg} \mathrm{cm}{ }^{2}\right)$ & $1237.1 \pm 16.6$ & $1244.8 \pm 13.9$ & $1233.5 \pm 13.5$ & $1222.7 \pm 9.700$ & $\mathrm{~ns}$ & ns \\
\hline CArea $\left(\mathrm{mm}^{2}\right)$ & $5.77 \pm 0.59$ & $5.79 \pm 0.46$ & $4.10 \pm 0.09$ & $4.22 \pm 0.190$ & 0.01 & 0.05 \\
\hline $\mathrm{I}_{\mathrm{MIN}}\left(\mathrm{mm}^{4}\right)$ & $4.35 \pm 1.00$ & $4.31 \pm 0.86$ & $2.41 \pm 0.25$ & $2.25 \pm 0.240$ & 0.01 & 0.05 \\
\hline $\mathrm{I}_{\operatorname{MAX}}\left(\mathrm{mm}^{4}\right)$ & $7.21 \pm 1.16$ & $7.77 \pm 1.44$ & $3.66 \pm 0.16$ & $4.55 \pm 0.490$ & 0.01 & 0.05 \\
\hline $\mathrm{I}_{\mathrm{P}}\left(\mathrm{mm}^{4}\right)$ & $11.56 \pm 2.57$ & $11.88 \pm 2.23$ & $6.07 \pm 0.36$ & $6.90 \pm 0.670$ & 0.01 & 0.05 \\
\hline $\mathrm{I}_{\operatorname{MAX}} / \mathrm{C}_{\operatorname{MAX}}\left(\mathrm{mm}^{3}\right)$ & $3.52 \pm 0.61$ & $3.53 \pm 0.41$ & $2.16 \pm 0.07$ & $2.19 \pm 0.200$ & 0.05 & 0.05 \\
\hline
\end{tabular}

The differences between CD Sham and CD Ovx or NU sham and NU Ovx are statistically significant at ${ }^{\mathrm{a}}: \mathrm{p}<0.05 ;{ }^{\mathrm{b}}: \mathrm{p}<0.01$ and ${ }^{\mathrm{c}}: \mathrm{p}<0.001$.

The statistical difference in bone parameters between CD Sham and NU sham or CD Ovx and NU Ovx is indicated in Significance column; ns = non significant

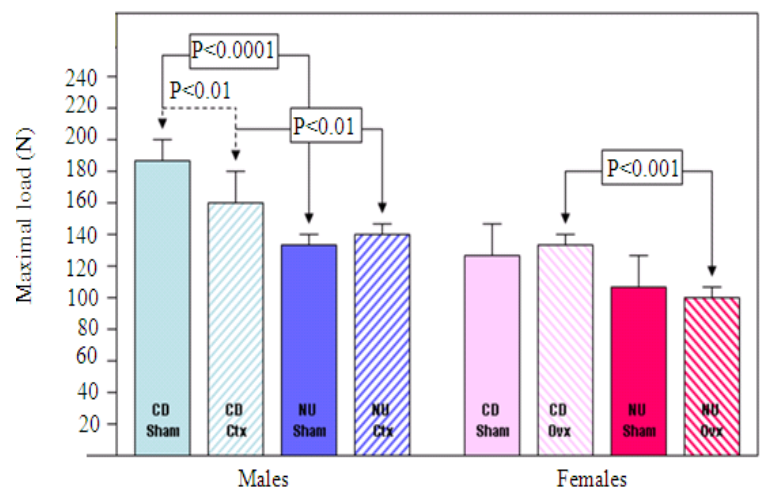

Fig. 3: Shows ultimate bone strength results obtained on excised femurs using 3 point bending method.

$\mathrm{CD}$ rats. Cortical bone properties were not significantly changed after Ovx in CD females, although Ovx resulted in increase bone marrow space, bone diameter and polar moment of inertia (Table 6, Fig. 2). Cortical bone strength was similar between sham and Ovx CD rats (Fig. 3). Ovariectomized NU females exhibited mild decrease in cortical thickness and mild increase in cortical bone parameters compared to sham nudes, but cortical bone strength between two groups of NU rats was similar. Ovariectomized CD females had stronger cortical bone compared to NU Ovx rats (Fig. 3).

\section{DISCUSSION}

It has been reported that aging athymic nude rats (6 months and older) accumulate in their peripheral lymphatic tissues (lymph nodes, spleen) $\mathrm{CD}^{+}$cells that superficially resemble $\mathrm{T}$ cells found in the same location in normal rats, although they express mostly $\alpha$ and $\beta$ TCR (Sarawar et al., 1991). Nude rats that are 8-12 months old express mostly CD4 or CD8 single positive cells in numbers that are approximately $50 \%$ lower compared to $\mathrm{T}$ cells found in normal rats (Schwinzer et al., 1987), but as mentioned earlier they lack alloreactivity in vivo and their TCR repertoire is more of an oligoclonal nature. In our pilot study, the lymphocyte subpopulations in normal and nude rats were identified by their unique antigen binding cell surface receptors. Three primary populations of lymphocytes were identified; B cells (the antigen presenting cells), two primary types of $\mathrm{T}$ cells; cytotoxic $\mathrm{CD} 8 \mathrm{a}^{+}$and helper, $\mathrm{CD} 4{ }^{+}$cells that release cytokines critical in immune response and finally the Natural Killer (NK) cells which respond to and kill abnormal cells. In addition, a small population of cells (NKT) positive for both the T and NK markers was identified; function of these is not known. The activated $\mathrm{T}$ cell population was further defined as CD25+ lymphoblasts and dendritic cells and RT1B+ MHC Class II expressing cells.

Our data shows that normal $\mathrm{CD}$ rats have significantly higher number of $\mathrm{T}$ lymphocytes, but 
lower number of B and NK cells compared to both strains of nudes. Both cytotoxic and helper T cells were present in significantly higher numbers in the blood of normal relative to nude rats. The two strains of nudes also show differences; CR source nudes have higher NKT, T, CD8a+ and RT1B+ levels while Taconic source nudes have more B lymphocytes compared to $\mathrm{CR}$ nudes. Taken together our data demonstrate significant heterogeneity in lymphocyte subpopulation between different strains of immunodeficient rats and scientists should be aware of these differences when using nude animals for skeletal research, in particular because role of lymphocyte subpopulations in skeletal biology is largely unknown (Schuurman, 1995; Schuurman et al., 1992).

In our study well described and controlled rat models (Ctx and Ovx) were utilized to investigate the difference in bone mass, structure and strength between normal and immunodeficient rats following castration or ovariectomy. Clearly there is a difference in body size and weight between normal and immunodeficient rats and this difference is also reflected in smaller skeleton of nude animals that should be taken into account when comparing bone mass, structure and strength between normal and nude rats. Both sex steroids (Harris et al., 1996; Orwoll, 1996) and immune system (David, 2007; De Martinis et al., 2007) are known to have profound effect on skeletal physiology. In addition to direct effect of estrogen on bone cells, preclinical studies have identified regulatory role of estrogen on adaptive immune physiology (Pacifici, 2008; Teitelbaum, 2004).

In our study there is a clear difference in body weight and size between Sham and Ctx CD males, but not between Sham and Ctx nudes, suggesting that immune status may influence the way body and skeleton reacts to deprivation of testosterone. Castrated $\mathrm{CD}$ rats showed significant decrease in cancellous and cortical bone parameters, as well as weaker cortical bone relative to CD Shams. On the contrary, NU Ctx rats showed only moderate decline in trabecular number; $20 \%$ relative to $38 \%$ recorded for CD Ctx rats. Decrease in trabecular number in NU Ctx rats was paralleled by mild decrease in trabecular connectivity and separation, while cortical bone parameters and cortical bone strength remained unchanged. It should be noted that in general intact NU males have more trabecular bone at secondary spongiosa compared to intact $\mathrm{CD}$ males and that superior trabecular connectivity and higher bone volume in nude males provides more substrate for bone loss following castration. Finally, castration had minimal effect on cortical bone in NU male rats and had no impact on cortical bone strength. Even though serum biomarkers of bone metabolism didn't show significant difference between experimental groups at the end of the study during steady state remodeling stage, PINp and osteocalcin data indicate that there could be a different response to testosterone and estrogen ablation between nude and normal rats and that these events could be more pronounced during the first and second remodeling cycle following $\mathrm{Ctx}$ and $\mathrm{Ovx}$ when bone metabolism is far more active as indicated by in vivo obtained microCT results.

Similar to males, NU Sham female rats had significantly more trabeculae at secondary spongiosa relative to $\mathrm{CD}$ Shams, resulting in better connectivity and improved BV/TV parameter. Nude females lost $41 \%$ of existing trabeculea due to ovariectomy relative to $51 \%$ observed in Ovx CD females and since nude females started with more trabeculea before Ovx surgery, NU Ovx rats ended up having 46\% more trabecular bone at secondary spongiosa of the distal femur compared to Ovx CD's at the end of study. Ovariectomy did not have major impact on cortical bone parameters or strength in both $\mathrm{CD}$ and $\mathrm{NU}$ females, probably as a result of modeling events at periosteal cortical bone envelope (Bagi et al., 1993; Frost, 1990).

Results from recent preclinical studies in mice have suggested that $\mathrm{T}$ cells play a key role in the regulation of bone loss after ovariectomy, in particular that $\mathrm{T}$ cells up-regulate osteoclast formation through the production of TNF alpha and the Receptor Activator of Nuclear Factor-Kappa B Ligand (RANKL) (Cenci et al., 2000; Roggia et al., 2001; Toraldo et al., 2003; Weitzmann et al., 2000). A central role has been postulated for IL-7, an inflammatory osteoclastogenic cytokine known for its ability to stimulate T and B cells in mice (Hofmeister et al., 1999). Our findings in rats suggest that there is considerable difference in bone mass and structure between normal and immunodeficient male and female rats and that those immmunodeficient animals have in general more cancellous bone compared to age matched immunocompetent rats. Our data also indicate that while deprivation of estrogen and testosterone leads to resorption driven bone loss in both normal and immunocompromised rats, the magnitude of bone loss in immunodeficient animals is of a smaller magnitude relative to normal rats. Lastly, study results suggest that cortical bone is not affected by immune status of the rats and that majority of skeletal changes are related to cancellous bone compartment which make sense since cancellous bone is in close contact with bone marrow and cells of the immune system. We 
hypothesized that noted differences in bone loss between normal and nude rats are probably due to regulatory role of immune system that affects both bone formation and bone resorption and that sex steroids may have on adaptive immune physiology, while the direct effect of estrogen and testosterone on bone cells is similar in normal and nude animals. To fully evaluate relevance of these findings for human osteoporoses more research needs to be conducted to establish if and how immune system in nude rats changes over time and how these changes affect bone remodeling (resorption and formation) by utilizing histomorphometrical methods in addition to frequent use of serum biomarkers and imaging modalities.

\section{CONCLUSION}

Although one should generally be cautious when extrapolating animal experimental findings to humans, this study would suggest that the immune system plays a significant role in bone homeostasis and it could be manipulated to provide partial protection from bone loss caused by ovariectomy and castration. This work supports concept that modulators of immune system could be welcomed addition to standard antiresorptive and anabolic therapies to treat osteoporoses of various etiologies.

\section{REFERENCES}

Andersen, C., C.M. Bagi and S.W. Adams, 2003. Intratibial injection of human prostate cancer cell line CWR22 elicits osteoblastic response in immunodeficient rats. J. Musculoskelet Neuronal Interact, 3 : 148-155. http://www.biomedexperts.com/Profile.bme/68521/ CM_Bagi

Bagi, C.M., N. Hanson, C. Andresen, R. Pero, R. Lariviere, C.H. Turner and A. Laib, 2006. The use of micro$\mathrm{CT}$ to evaluate cortical bone geometry and strength in nude rats: correlation with mechanical testing, pQCT and DXA. Bone, 38: 136-144. http://www.ncbi.nlm.nih.gov/pubmed/16301011

Bagi, C.M., M. Mecham, J. Weiss and S.C. Miller, 1993. Comparative morphometric changes in rat cortical bone following ovariectomy and/or immobilization. Bone, 14: 877-883. http://www.ncbi.nlm.nih.gov/pubmed/8155411

Bagi, C.M., G.W. Roberts and C.J. Andresen, 2008. Dual focal adhesion kinase/Pyk2 inhibitor has positive effects on bone tumors: implications for bone metastases. Cancer, 112: 2313-2321. http://www.ncbi.nlm.nih.gov/pubmed/18348298
Bellido, T., R.L. Jilka, B.F. Boyce, G. Girasole, H. Broxmeyer, S.A. Dalrymple, R. Murray and S.C. Manolagas, 1995. Regulation of interleukin-6, osteoclastogenesis and bone mass by androgens. The role of the androgen receptor. J. Clin. Invest., 95:

2886-2895. http://www.ncbi.nlm.nih.gov/pubmed/7769130

Benestad, H.B., I.B. Hersleth and B. Rolstad, 1989. Thymus and $\mathrm{T}$ cells are not essential for rat leucopoiesis. Eur J Haematol. 43: 150-157. http://www3.interscience.wiley.com/journal/12235 5340/abstract?CRETRY $=1 \&$ SRETRY $=0$

Cenci, S., G. Toraldo, M.N. Weitzmann, C. Roggia, Y. Gao, W.P. Qian, O. Sierra and R. Pacifici, 2003. Estrogen deficiency induces bone loss by increasing $\mathrm{T}$ cell proliferation and lifespan through IFN-gamma-induced class II transactivator. Proc. Natl. Acad. Sci. USA., 100: 10405-10410. http://www.ncbi.nlm.nih.gov/pubmed/12923292

Cenci, S., M.N. Weitzmann, C. Roggia, N. Namba, D. Novack, J. Woodring and R. Pacifici, 2000. Estrogen deficiency induces bone loss by enhancing T-cell production of TNF-alpha. J. Clin. Invest., 106: 1229-1237. http://www.ncbi.nlm.nih.gov/pubmed/11086024

David, J.P., 2007. Osteoimmunology: a view from the bone. Adv. Immunol. 95: 149-165. http://www.ncbi.nlm.nih.gov/pubmed/17869613

De Martinis, M., C. Franceschi, D. Monti and L. Ginaldi, 2007. Apoptosis remodeling in immunosenescence: implications for strategies to delay ageing. Curr. Med. $\quad$ Chem. 14: 1389-1397. http://www.ncbi.nlm.nih.gov/pubmed/17584051

Festing, M.F., D. May, T.A. Connors, D. Lovell and S. Sparrow, 1978. An athymic nude mutation in the rat. Nature, 274: 365-366. DOI: 10.1038/274365a0

Frost, H.M., 1990. Skeletal Structural Adaptations To Mechanical Usage (SATMU): 4. Mechanical influences on intact fibrous tissues. Anat. Rec., 226: 433-439. http://www.ncbi.nlm.nih.gov/pubmed/2184697

Goldring, S.R., 2003. Inflammatory mediators as essential elements in bone remodeling. Calcif. Tissue. Int., 73: 97-100. DOI: 10.1007/s00223002-1049-y

Guise, T.A. and G.R. Mundy, 1998. Cancer and bone. Endocr. $\quad$ Rev., $\quad 19$ : 18-54. http://www.biomedexperts.com/Abstract.bme/9494 779/Cancer_and bone

Hanson, N.A. and C.M. Bagi, 2004. Alternative approach to assessment of bone quality using micro-computed tomography. Bone, 35: 326-33. http://www.journals.elsevierhealth.com/periodicals /bon/article/S8756-3282 (04)00075-4/abstract 
Harris, S.A., K.R. Tau, R.T. Turner and T.C. Spelsberg, 1996. Estrogens and progestins. In: Principles of Bone bIology. Systemic Hormones that Influence Bone Metabolism, Bilezikian J.P., L.G. Raisz, G.A. Rodan (Eds.). Academic Press, San Diego, ISBN: 0-12-098650-7, pp: 507-520.

Hofmeister, R., A.R. Khaled, N. Benbernou, E. Rajnavolgyi, K. Muegge and S.K. Durum, 1999. Interleukin-7: Physiological roles and mechanisms of action. Cytokine Growth Factor Rev., 10: 41-60. http://www.ncbi.nlm.nih.gov/pubmed/10379911

Kalu, D.N., 1991. The ovariectomized rat model of postmenopausal bone loss. Bone Miner., 15: 175-191. http://www.ncbi.nlm.nih.gov/pubmed/1773131

Kanis, J.A., O. Johnell, C. De Laet, B. Jonsson, A. Oden and A.K. Ogelsby, 2002. International variations in hip fracture probabilities: Implications for risk assessment. J. Bone Miner. Res., 17: 1237-1244. http://www.ncbi.nlm.nih.gov/pubmed/12096837

Lelovas, P.P., T.T. Xanthos, S.E. Thoma, G.P. Lyritis and I.A. Dontas, 2008. The laboratory rat as an animal model for osteoporosis research. Comp. Med., 58: 424-430. http://www.ingentaconnect.com/content/aalas/cm/2 008/00000058/00000005/art00001

Orwoll, E.S., 1996. Estrogens and Progestins. In: Principles of Bone Biology. Systemic Hormones that Influence bone Metabolism, Bilezikian, J.P. Raisz L.G., Rodan G.A. (Eds.)., Academic Press, San Diego, ISBN: 0-12-098650-7, pp: 563-580.

Pacifici, R., 2008. Estrogen deficiency, T cells and bone loss. Cell Immunol., 252: 68-80. DOI: 10.1016/j.cellimm.2007.06.008

Raisz, L.G., 2005. Pathogenesis of osteoporosis: concepts, conflicts and prospects. J. Clin Invest., 115: 3318-3325. DOI: 10.1172/JCI27071

Renz, J.F., Z. Lin, M. de Roos, A.A. Dalal and N.L. Ascher, 1996. SCID mouse as a model for transplantation studies. J. Surg. Res., 65: 34-41. http://www.journalofsurgicalresearch.com/article/S 0022-4804(96)90340-6/abstract

Ritchie, R.O., K.J. Koester, S. Ionova, W. Yao, N.E. Lane and J.W. Ager, 2008. Measurement of the toughness of bone: a tutorial with special reference to small animal studies. Bone, 43: 798-812. http://www.journals.elsevierhealth.com/periodicals /bon/article/PIIS8756328208003104/abstract

Roggia, C., Y. Gao, S. Cenci, M.N. Weitzmann, G. Toraldo, G. Isaia and R. Pacifici. 2001. Up-regulation of TNF-producing $\mathrm{T}$ cells in the bone marrow: A key mechanism by which estrogen deficiency induces bone loss in vivo. Proc. Natl. Acad. Sci. USA., 98: 13960-13965. DOI: 10.1073/pnas.251534698
Rolstad, B., 2001. The athymic nude rat: an animal experimental model to reveal novel aspects of innate immune responses? Immunol. Rev., 184: 136-44. http://www.ncbi.nlm.nih.gov/pubmed/11918682

Sarawar, S.R., C.P. Yang and E.B. Bell, 1991. T-cell receptor-bearing cells from athymic nude rats respond to alloantigen in vitro but are defective in vivo. Immunology, 73: 334-341. http://www.ncbi.nlm.nih.gov/pmc/articles/PMC1384552/ Schuurman, H.J., 1995. The nude rat. Hum. Exp. Toxicol., 14: 122-5. DOI: 10.1177/096032719501400130

Schuurman, H.J., E.B. Bell, K. Gartner, H.J. Hedrich, A.K. Hansen, B.C. Kruijt, P. De Vrey, R. Leyten, S.J. Maeder, R. Moutier et al., 1992. Comparative evaluation of the immune status of congenitally athymic and euthymic rat strains bred and maintained at different institutes: 2. Athymic rats. J. Exp. Anim. Sci., 35: 33-48. http://www.ncbi.nlm.nih.gov/pubmed/1606201

Schwarz, B.A. and A. Bhandoola, 2004. Circulating hematopoietic progenitors with $\mathrm{T}$ lineage potential. Nat. Immunol., 5: 953-960. DOI: 10.1038/ni1101

Schwinzer, R., H.J. Hedrich and K. Wonigeit, 1987. The alloreactive potential of T-like cells from athymic nude rats (rnu/rnu). Transplant Proc., 19: 285-287. PMID: 2978903

Teitelbaum, S.L., 2004. Postmenopausal osteoporosis, $\mathrm{T}$ cells and immune dysfunction. Proc. Natl. Acad. Sci. USA., 101: 16711-17612. DOI: 10.1073/pnas.0407335101

Thompson, D.D., H.A. Simmons, C.M. Pirie and H.Z. Ke, 1995. FDA Guidelines and animal models for osteoporosis. Bone, 17: 125-133. http://www.ncbi.nlm.nih.gov/pubmed/8579908

Toraldo, G., C. Roggia, W.P. Qian, R. Pacifici and M.N. Weitzmann, 2003. IL-7 induces bone loss in vivo by induction of receptor activator of nuclear factor kappa B ligand and tumor necrosis factor alpha from T cells. Proc. Natl. Acad. Sci. USA., 100: 125-30. http://www.ncbi.nlm.nih.gov/pubmed/12490655

Vanderschueren, D., L. Vandenput, S. Boonen, M.K. Lindberg, R. Bouillon and C. Ohlsson, 2004. Androgens and bone. Endocr. Rev., 25: 389-425. http://edrv.endojournals.org/cgi/content/full/25/3/389

Weitzmann, M.N., S. Cenci, L. Rifas, C. Brown and R. Pacifici, 2000. Interleukin-7 stimulates osteoclast formation by up-regulating the T-cell production of soluble osteoclastogenic cytokines. Blood, 96: 1873-1878. http://www.ncbi.nlm.nih.gov/pubmed/10961889

Zhau, H.E., C.L. Li and L.W. Chung, 2000. Establishment of human prostate carcinoma skeletal metastasis models. Cancer, 88: 2995-3001. http://www.ncbi.nlm.nih.gov/pubmed/10898343 